\title{
Aid and irritants in Pak-US relations in the wake of 9/11 incident
}

\author{
Shahid Yaqoob* | Noman Sattar \\ Area Study Center, Quaid-i-Azam University, Islamabad, Pakistan. \\ *Correspondence Emails: syaqoob153@gmail.com | pakirish@yahoo.com
}

\begin{abstract}
This paper analyses the nature of post 9/11 relations and its impact on South Asia especially Pakistan. Pak-US relations have been perplexing and intricate since inception of their relations. This relationship manifests the classical example of convergence and divergence of national interests. Client-patron state relations between Pakistan and United States measure level of interaction and commitments. The 9/11 was a hapless event, which drastically changed the scope of relationship and level of engagement. This dastard act was the tipping point of revitalized bilateral relationship in altogether different circumstances. United States was bent on hunting perpetrators of heinous act of $9 / 11$ at any cost and it was not possible without cooperation and facilitation of Pakistan being next door neighbour of Afghanistan. Pakistan grabbed this opening to end international isolation and overcome its economic handicaps. Pakistan again became strategic partner of US in war on terror and being frontline state earned the title of the US major non-NATO ally. However, the relations remained fraught due to various allied factors such as distrust and lack of confidence. This paper tries to analyze the impact between aid given to Pakistan, in the context of irritants between civil and military regimes in Pakistan.
\end{abstract}

\section{Article History}

Received:

January 27,2021

Last Revised:

May 21, 2021

Accepted:

May 25, 2021

Published:

June 16, 2021

Keywords: alliances, coalition support fund, irritants in bilateral relations, Pak-US engagement, frontline state, non-NATO ally, client patron relations, do more mantra.

\section{How to Cite:}

Yaqoob, S. \& Sattar, N. (2021). Aid and irritants in Pak-US relations in the wake of 9/11 incident. Liberal Arts and Social Sciences International Journal (LASSIJ), 5(1), 266-278. https://doi.org/10.47264/idea.lassij/5.1.18

\section{Publisher's Note:}

IDEA PUBLISHERS (IDEA Journals Group) stands neutral with regard to the jurisdictional claims in the published maps and the institutional affiliations.

Copyright: () 2021 The Author(s), published by IDEA PUBLISHERS (IDEA Journals Group). This is an Open Access article published under the Creative Commons Attribution-NonCommercial 4.0 International License (http://creativecommons.org/licenses/by-nc/4.0/) 


\section{Introduction}

Post-World War II international politics witnessed increased ideological struggle between communist and capitalist forces, which immensely impacted the world order and polarized the world. These evolving trends shaped new patterns and trends in international politics. Owing to close proximity of USSR with Asian states, newly created states were more vulnerable to such threats to their existential identity. Being a newly conceived state, Pakistan initially pursued the independent policy of non-alignment as a sign of goodwill, mutual respect and friendship to all the nations. However, such policy of maintaining aloofness and neutrality in respect of major global issues was neither viable nor favourable to vital national interests of Pakistan. Since independence, Pakistan had inherited various fundamental issues like boundary disputes, Kashmir, refugees rehabilitation, unjustified share in resources, political and economic instability etc. These internal issues were major reasons to shun dormant and isolationist policy and start exploring new options in international arena. However, Indian invasion for acquiring princely state of Kashmir was major blow to neutral stance of Pakistan, as it had no well-equipped army to confront its potential rival. These conditions gave rise to a situation, which demanded leadership at the helm of affairs to revisit foreign policy as per needs and requirements (Saniel, 2018; Raza, 2020; Baverley, 2020)

US considered Pakistan as an ill-conceived state immediately after its inception. The American inclination was toward India in the region as they had been supporting Indian National Congress as an important ally before partition of subcontinent. They did not have any sympathy or soft corner for Muslim League. After partition there was no such consideration for Pakistan as it was for India. The initiative was taken by Prime Minister Liaqat Ali Khan by undertaking visit of United States in May, 1951 and giving an explicit message to the world that the Pakistani foreign policy preference had in no case Communist preference. Korean War gave a wonderful opportunity to Pakistan to win an important position. Later, Pakistan was engaged in alliances aimed at security against communist regime of former USSR. But after this when Pakistan tried to diversify the policy, the relations lost warmth (Burke \& Ziring, 1990).

Initially, US found best possible front-line state and client state in form of Pakistan owing its geostrategic and geopolitical position. As Pakistan was in dire need of military and economic assistance at that crucial stage of its history hence it readily accepted US terms of engagement and cooperation to combat growing threat of communism in the region. This bilateral alliance was vital to open new avenues of mutual understanding and agreement. Pakistan further entered into various treaties and alliances like Southeast Asian Treaty Organization (SEATO) in 1954 and Central Treaty Organization (CENTO) with the co-operation of Turkey in 1955 as a measure to protect communism invasion (Mirza, 2020; Saud, 2018). The Sino-Indian conflict in 1962 proved a major point of reckoning as US imposed sanctions on military equipment for Pakistan. Pak-India war of 1965 was major test of US friendship and alliance. However, US did not extend any help to its client state and treated both India and Pakistan on equal footing creating embarrassing situation in the region. Pakistan's acceptance of USSR backed Tashkent Agreement with India alienated US to some extent as it was first tangible effort of Pakistan to woo its potential competitor of US. This development was nasty blow to much touted US approach in South Asia as it further triggered political upheaval in Pakistan.

However, President Nixon exploited the good office of General Yahya Khan for establishing diplomatic ties with China as Pakistan was enjoying amicable relations with people republic of China. This diplomatic facilitation helped win soft corner from Nixon administration, which 
could not avert disintegration of Pakistan in 1971. The new government inspired by China model followed some progressive and non-conventional policies resulting into major policy shifts in the region. Pakistan quest for nuclear weapons as a counter balancing act to Indian threat was main source of US indignation as US was vehemently opposed to any such overtures by an Islamic country (Khan, 2020; Khawaja, 2019).

During the period until 1979 both countries were having relations at the lowest ebb as US was not willing to let Pakistan develop nuclear program. However, the Soviet invasion in Afghanistan was a triggering factor, which brought Pakistan into limelight again. With USSR invasion of Afghanistan, political equation changed altogether as Pakistan again became epicentre of new global conflict owing to its geopolitical and geostrategic location. US approached Pakistan for combating Communist agenda in Asia. Owing to its geostrategic and geopolitical significance the war in Afghanistan was fought on our soil. United States prepared Pakistan to fight a proxy war in Afghanistan. Pakistan again accepted this offer and acted as front-line state in containing Russian advancement in the region which was vital to US interests. The Muslim Mujahideen from all over the world gathered at a place to get recruited and trained, which was Pakistan. Pakistan relation with Islamic block, Iranian revolution and oil factor also affected the prevailing political trends. Owing to crucial role in Afghanistan against USSR, Pakistan was second largest recipient of aid after Israel in terms of military, economic and logistic support. In 1981, US Congress authorized an aid package of 3.2 billion dollars for Pakistan and Forty F-16 fighter jets. Another aid package of \$4 Billion was authorized for period of five years (1979-1984) (Akhtar, 2012).

As soon as former USSR withdrew from Afghanistan United States left the region without considering the aftermath for Pakistan. Pakistan was alone to take care of Afghan refugees and face Afghan civil war. This created a trust deficit again in Pakistan that United States again left Pakistan in dire crisis. Moreover, with the disintegration of USSR, US again started losing interest in Pakistan owing to divergence of national interests. US again slapped military and economic sanctions on Pakistan for lacking in democratic dispensations and pursuit of nuclear weapons program. It was time when India was emerging as rapidly evolving economy and being largest functional democracy, US was equally interested to foster close ties with India as containment measure against communist China. The real point of altercation was the nuclear explosion carried out by Pakistan in response to Indian action in Pokhran in 1998. US immediately put immense diplomatic pressure to isolate Pakistan in comity of nations. However, with China and Saudi financial assistance and backing it succeeded in averting collapse of its fragile economy. Pakistan was bent on securing and protecting its sovereignty by maintaining minimum deterrence against its hostile neighbour (Sasikumar, 2017).

The era of 1990s is not marked with any significance in relations. Although United States had been espousing the cause of democracy in Pakistan yet the practical engagement was observed with military regimes. The core reason remains the strategic interests of United States. The toppling of civilian government by military led coup in 1999 drew criticism from international community. Pakistan was experiencing worst kind of political isolation and economic crisis as major powers were not legitimizing such dictatorship in modern era. At the time of 9/11, Pakistan was under sanctions due to nuclear explosions and military coup by General Pervaiz Musharraf. Immediately after 9/11 when Pakistan decided to join Global War on Terror the relations between US and Pakistan witnessed tremendous boom. US needed Pakistan for air blanket, logistic support and air bases. The decade of partnership and cooperation continued at the cost of democracy in Pakistan (Ahmad, 2011; Salim et al., 2018). 
Thus, the hapless event of 9/11 changed the equation and shaped new world order. US was bent on eliminating Al-Qaeda and Taliban who had perpetrated this heinous act of terrorism. This event again came as bolt from blue as it afforded another opportunity to Pakistan to reap the benefit of US friendship and cooperation. Therefore, Pakistan was warmed to decide its future course of action whether it was with US or not, as US was determined to wage a war against terrorists on global front. Pakistan again became strategic partner of US in war on terror and being frontline state earned the title of the US major non-NATO ally. US provided help and assistance in defence, trade, education, science and technology. Pakistan aptly harnessed this relationship by developing and upgrading its security apparatus and equipment. Pakistan provided air space and logistic support to conduct air strike $\mathrm{s}$ and ground operations in terrorist dens in Afghanistan. Pakistan conducted operations in its northern areas bordering Afghanistan and apprehended many fugitive terrorists fleeing from active zones. However, this closed cooperation led to sharp rise in terrorist activities in Pakistan bring normal life to standstill as fear and uncertainty gripped the atmosphere. Similarly, frequent drone attacks on bordering region sparked protest and anger amongst local tribesmen as many innocent lives were taken by erroneous strikes. Pakistan government was on board for such strikes as it only issued symbolic statements of condemnation for violation of national sovereignty of Pakistan (Khan, 2019; Niazi, 2017).

\section{Theoretical aspect}

International relation discipline is a comprehensive area of study which deals with political, economic, military and cultural relations amongst nations. It enunciates salient features and principles which shape and develop understanding amongst nations. As a result of such dispensations, nations map out their future overtures. This framework is supported by multiple theories. This theory of cooperation underscores a particular dimension of cooperation within legal approach which may be termed as alliances. Alliances are the most vital facet of international relations. Alliances are also subjected to factors and theories that can be categorized as geographical, political and ideological. Number of scholars presented their theories to scrutinize the dynamics of alliances between nations. Each theoretical framework further elaborates multiple aspects of geography, politics and ideology to rationalize the system of alliances between nations. The decisive factor in regulating international politics is national interest of any given state that culminates into continuous competition among states. States are duty bound to provide protection to its citizens and assure the security of the state itself. Therefore, on world stage we can see states striving for power, enhancing their military stature and improving the economic capacity of state against others.

In global politics the eventual goal of a state is to increase its power that will assure its security and enhances its capacities. While securing their national interest states even join military alliances, though, every state has its own objectives of joining the alliances. Alliances are used by both the weaker countries and stronger countries to seek and cater the protection of its national interests. US invited Pakistan to join hands in the Cold war defence alliances since they had their own interest to serve while Pakistan had joined it to serve their own interest, thus two countries enter into alliance if their interest coincides. However, to George Liska, conflict is the cardinal factor that evolves alliance system in global politics. Nevertheless, other factors play their roles as well but they cannot be placed on the same footing. This is an obvious fact that asymmetrical alliances have their roots in conflict; otherwise, such alliances are not feasible for both the allies. Alliances based on conflicts may be classified as domestic, regional and international. Domestic alliances involve third party from outside for adding credibility to 
their actions to become a part of international system. In asymmetrical alliances both the allies enjoy circumscribed benefits by mutual sharing of resources.

The alliances can be categorized as balancing alliance and band wagoning alliances. The balancing alliances are defensive while band wagoning alliances are aggressive in nature. Most of the weaker states prefer band wagoning since they add more to the aggressive threat by aligning with it. However, band wagoning enhances the leverage of great power since it protects its national security interest at regional as well as global level while the weak states adjoining its power to secure its national security interest in the periphery (Amin, 2020; Aguirre, 2019).

\section{Research Methodology}

The research has been carried out by employing historical, descriptive and analytical approaches enabling to draw conclusion. Different resources like review of literature, primary and secondary sources have been consulted to get broader perspective to the cause of Pakistan's membership to U.S sponsored Western pacts and its repercussions on the region. Primary data has been collected through interviews, declassified papers, autobiographies of persons at the affairs. Semi-structured personal interviews were conducted with scholars, government officials and retired and in-service military personnel.

\section{Discussion and findings}

\subsection{The irritants in Pak-US relations}

Preservation of independent status in the comity of nations is the hallmark of foreign policy of all sovereign countries. However, the history of relations between Pakistan and United States has always been rocky, complex and frictional. The element of mistrust has always prevailed the relations, overshadowing the level of engagement. There are various factors, which have always marred the relations. The history of this engagement dates back to pre-partition, with Liaquat Ali Khan paid first visit to United States and elicited preference over former USSR. This was the event, which triggered the relationship by declaration of Pakistan's tilt towards United States. The engagements and disengagements during different phases gave rise to trust vacuum. The 9/11 turned the tide and Pakistan became crucially important for Operation Freedom. At that time Pakistan was under strict sanctions due to nuclear tests and military coup of General Musharraf. After that Global War on Terror determined the level of engagement. Pakistan played a crucial role in this war being a neighbour to Afghanistan and strategically important for land route and logistic support. However, the relations remained fraught due to various allied factors such as distrust and lack of confidence (Nazar, 2003; Naqvi, 2007).

There are other factors, which hinder this process of mutual cooperation and there are various events, which spoiled the relationship. The increased extremism and militancy in Pakistan, killing of Osama Bin Laden, attack on Salala check post, and arrest of CIA operative Raymond Davis are plausible irritants in this bilateral relationship (Akhtar, 2012). The research paper "Re-defining US-Pakistan Relations" by Naeem Ahmad examines the impact of 9/11 in triggering reinvigoration in Pak-US relations. The succeeding War on Terror prolonged this engagement. The researcher scrutinizes this decade's engagement from three aspects; aid funnelled into Pakistan, cooperation between Bush administration and Musharraf government despite American rhetoric in support of democracy in Pakistan, and upheavals in relationship 
due to various turbulent events. USA had been stressing upon Pakistan to take action against various Taliban factions and deny them safe havens within Pakistani territory. This constant demand became the cause of annoyance in Pakistan. Drone strikes in particular added to anger in general public in Pakistan (Ahmad, 2011).

Murad Ali in his article "US foreign aid to Pakistan and democracy: An Overview" analyses the relationship of aid given to Pakistan and support for military dictatorships and civilian governments. This paper covers era from 1947 to 2006. The quantitative analysis of the data of aid provides a clear picture far higher aid to military dictatorships than civilian governments. The American support for military dictatorships has its vested interests in the region. The military dictatorship of General Ayub Khan was inevitable in Cold War. The Zia regime was equally unavoidable in Afghan war and Musharraf was key ally in GWOT. The aid is always associated with conditionality i.e., benchmark on the part of recipient. The effectiveness of aid can be assured in democracies not autocracies (Ali, 2009).

The trust deficit in Pakistan-US relationship was major cause of turbulent course. Bruce Riedel takes a strong tone in describing Pakistan-US relations in "Deadly Embrace" in which he asserts that relation with Pakistan is integral but highly harmful. Taking note of all irritants he describes that friction in the relations increases due to Pakistan's double games and not by varied interpretations of mutual interests. As Director Central Intelligence Agency, he had been close to Pakistan's intelligence agencies and he avers the mess in Afghanistan and tribal belt of Pakistan as brewed by Pakistan itself. He takes a biased stance by putting whole blame on Pakistan of security concerns in Pakistan, Afghanistan and South Asia. This piece of writing entirely focuses on loopholes in Pakistan's security system and declares it intentional double game (Riedel, 2011).

\subsection{The 9/11: A focusing event}

The eventful day of September 11, 2001, changed the face of world. It was such an event with far reaching impacts and repercussions. Until September 10th, the relations between Pakistan and United States were at lowest ebb. Pakistan was slapped with sanctions for nuclear explosions and also democracy sanctions were imposed due to military takeover of Gen. Musharraf. 9/11 event triggered a wave of change worldwide. It was crystal clear that Pakistan has to be integral part in succeeding events. US accords and details of consultation, which became public later, confirmed that it was decided on 11th September that Pakistan, Afghanistan and Arab World would be delivered clear message to take action against terrorists (Sattar, 2010). Al- Qaeda had been declared the responsible for attacks on US soil.

Pakistan had to decide on this impending war on terror with rational approach. This sole event made Pakistan frontline ally in War on Terror. The world was moved by this act. UN Security Council passed three resolutions in three days i.e., 1368, 1373 and 1377 (Sohrab and Chaudhary, 2012). The world was urged to take action and it was decided to freeze assets of terrorists (Rizvi, 2005). The long era of lukewarm relations between United States and Taliban had ended up after their refusal to surrender Osama Bin Laden. Pakistan was forced to exert its influence on Taliban. Later, Pakistan had to make choice either to sever relations with Taliban or face the consequences.

The benefits of this new engagement with US soon became clear to Pakistan. Lifting of sanctions and aid was the first step, which ensured the new partnership. Firstly, the Brownback- 
II Amendment authorized US President to withdraw 'democracy sanctions' as a). In 2004, Ackerman amendment waived nuclear sanctions for five years. b). The US president sanctioned a waiver to allow resumption of assistance and military sales. Secondly, US agreed to immediately write off a part of Pakistan's debt and provided $\$ 600$ million as economic aid and $\$ 177$ million as military and security assistance for 2002. Thirdly, in 2003, Bush Administration decided to give \$ 3 Billion in Economic and Military assistance (Sattar, 2010). Pakistan was bestowed the status of 'non-NATO ally'. This event suddenly abridged the gap between US and Military regime of Pakistan. Bush Administration did all, which it could to emboldened Musharraf's Government in Pakistan. Pakistan was promised that it could buy F16 fighter jets once in Zia era. Other Military equipment was also sold to Pakistan and loans were on soft terms.

The change of stance was clearly in the wake of emergence of US interests in the region with another decade of engagement in Afghanistan. Pakistan had this reservation that after disintegration of Soviet Union, US immediately neglected the region without considering implications for Pakistan and regional security. Certainly, Pakistan confronted the blow of unstable political and economic conditions in Afghanistan and its own tribal belt. 9/11 was the event, which ushered in new era and determined US immediate commitments in Afghanistan. Pakistan was only country in region, which could be an ultimate security support and logistical help. This was the focusing event, which became catalyst of foreign policy decision-making and it had to decide its future course of action within hours and it did.

\subsection{Financial aid and impacts on Pak-US relations}

The relationship and level of engagement between United States and Pakistan have always been evaluated by the amount of aid extended to Pakistan. Immediately after 9/11, aid increased manifolds and sanctions were removed. United States has been extending aid to Pakistan for boosting economic and military capabilities to fight this war being frontline state against War on Terror. With demand to 'do more', United States provided this support for capacity building and to fight and eliminate terrorist safe havens within Pakistani territory. Their interests were converged after 9/11. When there was divergence, Aid was reduced or declined as we witnessed in Benazir Bhutto era. The major areas for US assistance were military and economic aid. In the Military Aid there were three kinds of Military Aid received by Pakistan.

4.3.1. Coalition support fund is received by 27 nations included in War on Terror as reimbursement. This support aimed at maintaining forces in tribal areas of Pakistan.

4.3.2. Pakistan's counterinsurgency capability fund was designed for Pakistan for carrying out activities in counterinsurgency in Pakistan. It was constituted under Supplemental Appropriations Act, 2009 for the fiscal year 2010.

4.3.3. Foreign military financing is consisted of grants and loans to acquire military hardware. It is dedicated to those states, which are important for United States' regional goals. Pakistan acquires obsolete US military hardware through this fund (SASSI, 2011).

\subsection{The civilian aid}

The civilian aid was extended to various sectors including health, education, disaster management, refugees and development of FATA. 
4.4.1. Economic support funds: It comprised of $80 \%$ of all Aid extended to Pakistan. It was high in 2010 due to floods.

4.4.2. International disaster assistance and migration and refugees assistance: It is provided to the effectives of disasters and refugees. This was allocated to Pakistan for disaster effectives of 2005, 2010 and foe displaced people due to War on Terror. It is mostly diverted from ESF.

4.4.3. FATA development plan: It was initiated in 2003 to help the under privileged inhabitants of FATA and carry out development projects there.

4.4.4. Enhanced partnership with Pakistan Act, 2009 OR Kerry Lugar Bill: This Act was passed in 2009 to triple the civilian aid to Pakistan. It was envisaged to extend \$ 1.5 billion every year from 2010 to 2014.

4.4.5. Friends of democratic Pakistan: This was held in 2009 in Tokyo to extend \$ 5.28 Billion in next five years (SASSI, 2011).

At the time of $9 / 11$ the level of aid was lowest rather Pakistan was under embargo. The immediate impact was extension of $\$ 500$ million to Pakistan after it decided to enter into war on terror (Sattar, 2010). Later the level of aid kept on increasing throughout the decade. The loan of $\$ 2$ billion was waived off (Cohen, 2007).

Pakistan did not have a well-devised plan while entering into War on Terror. But it was mindful of benefits it would get in form of aid. Some of the aid facts are:

- Pakistan was extended \$600 million emergency cash transfer in September 2001

- US assistance to Pakistan was \$ 36.76 million in FY 2000.

- During FY 2001 it increased fivefold to \$ 187.7 million.

- During FY 2002 the aid increased by eleven fold to $\$ 2000$ million.

- During 2003, Bush administration promised to $\$ 3$ billion five-year Aid package, which initiated in 2005.

- $\quad$ The aid surged during 2006 to 2010.

- In 2007, first development plan was given for tribal areas.

- In 2010, Pakistan was second among aid recipients from US after Afghanistan as aid reached the figure of $\$ 4.3$ billion.

- In 2012, Pakistan received \$ 2.1 billion in aid and ranked third among aid recipients.

- From 2002 to 2012 , about two-third of the aid went to security sector amounting at $\$$ 15.8 billion

- During 2013, National Defence Authorization Act 2013 limited the reimbursement to $\$ 1.2$ billion. The reduction is owing to closure of Ground Lines of Communication from November, 2011 to July 2012. The reimbursement was also stopped for the period of seven months (Epstein \& Kronstadt, 2013).

\subsection{Enhanced partnership with Pakistan Act 2009}

EPPA or Kerry Lugar bill was an effort to increase economic assistance to Pakistan reaching out to all sectors. It was strongly supported by Obama administration to enhance partnership 
with Pakistan in all sectors. It authorized to outspread $\$ 1.5$ billion in US economic assistance but after the certification of Secretary that Pakistan was taking appropriate measures to curb militancy and terrorism. This aid package could be extended from 2015 to 2019 if Pakistan is advancing towards democracy and stability (Epstein and Kronstadt, 2013). The attachment of aid, to certain conditions or 'benchmarks', makes it dependent on those events. This reduces the efficiency of the aid and the role played by it in determining the level of relationship.

\subsection{Regional interests}

Pak-US relations have been affected by various events hindering the process of cooperation. The impact of these irritants is assessed immediately on aid. In 2011, United States withheld the reimbursement of $\$ 800$ million to Pakistan. It was due to so many events becoming the root cause of mutual disagreement and acrimony. The cooperation is dependent upon United States' regional interests. Until the interests are met and United States is able to achieve the goals smoothly through cooperation the relations remain smooth. Diverging interests cause considerable problems in relations.

\subsection{Doubts about Pakistan role}

The perception in US about Pakistan's role in War on Terror is somehow doubtful due to Pakistan army's dominant role over policy. The view is that Pakistan army is not ready to take action against certain militant groups due to their proximity and interests with them. Pakistan has vested interests in supporting and controlling such groups (Timothy, 2011). The perception is developed due to Pakistan's lethargy in taking action against certain groups. The main problem arises at Haqqani group. Similarly, United States had been urging to take action in North Waziristan, which Pakistan is reluctant to take. The friction is now also on Pakistani inclination to talk to some militant factions. United States has clearly stated that if Pakistan is hesitant to take any action against such sanctuaries US will do itself which exacerbated the rhetoric in Pakistan against US (Rafique, 2012).

\subsection{Economic interests in India}

President Obama's 'pro-India' policy owing to is a perplexing issue for Pakistan. President did not make a stopover in Pakistan in October 2010, while visited India. This issue added to bitterness and trust deficit in Pakistan. Pakistan has always weighed India-US closeness as a threat to its security. The Afghan decision to make overt close links with India is making the minds in Pakistan that it is being encircled by external threat (Kronstadt, 2012). The civil nuclear deal between India and US is also a source of disturbance for Pakistan. At the time of signing the deal on October 8th, 2008, President Bush called India and US as 'natural partner'. This has added much to dent the relations (Ahmad, 2011). Pakistan has also asked for similar deal so many times, but it was refused by making the argument that Pakistan was not that much responsible state and capable of that technology.

US is particularly concerned about the state of extremism in Pakistani society. Assassination of Governor of Punjab, Salman Taseer, due to his certain remarks on Blasphemy Law in Pakistan was provoking for US. His killing by his own guard on January 4th, 2011 and later mass appreciation of his killer was seen in United States as haunting event. The same year on March, 2nd Federal Minister for Minorities was killed. He was Christian and only non-Muslim minister in federal cabinet. This event was particularly seen as violation of minorities' rights 
in Pakistan. These proved to be irritants in Pak-US relations. United States urged Pakistan time and again to take care of continuous violation of rights in Pakistan (Kronstadt, 2012).

For example, killing of two Pakistanis in accident in January 2011 caused by an American official of Consulate in Lahore was a much impulsive event. This issue lingered on for long despite of frantic US efforts to seek his freedom by diplomatic immunity. But this issue enhanced anti-US sentiment in Pakistan and the release of Raymond Davis by paying blood money further intensified this criticism (Akhtar, 2012). The killing of Saleem Shehzad, a journalist, in 2011, again raised hue and cry in USA over deteriorated human rights conditions in Pakistan and insecurity of journalists in particular. This murder was blamed on Pakistan. In a rare statement made by Pakistan's intelligence agency, ISI, declared that it did not have any role in his killing. Admiral Mike Mullen even went public in attributing this killing to Pakistan (Times, 2011).

\subsection{Osama Bin Laden as a cause of irritant}

The killing of Osama Bin Laden on May 2, 2011 in Abbottabad Pakistan near to Federal Capital, was a major blow to Pakistani relations with United States. The highest value target was found residing in Pakistan in vicinity of Federal Capital was enough to bring international criticism to Pakistan and deterioration of its image. It was not clear whether Pakistani security agencies were aware of his presence there. But in both cases it was indicating to the doubtful role of Pakistan. If his presence was not known than it was a question mark on the competency of agencies or either the close collaboration with enemy of United States (Kronstadt, 2012).

Pakistan's anger also reached its culmination by the event of Salala attack. ISAF declared it as the unintentional incident. But Pakistan deemed that it may be intentional act by NATO forces. This was the event which invoked practical action from Pakistan. Pakistan reacted by blocking Ground Lines of Communication, the way for logistic supplies to NATO forces inside Pakistan (Nawaz, 2011). The anger in Pakistan reached the level that apology from United States was urged. This matter lingered on till July, 2012, when Secretary of State, Hillary Clinton said 'sorry'. The irritants affect the relations and project downturn trajectory in bilateral engagements. The series of events occurred in 2011, negatively affected the relations. In case of Pak-US relations the impact is felt by strong rhetoric in United States and resultant reduction in aid. In July 2011, according to Congressional and State Department sources, \$440-\$500 million counterinsurgency reimbursements were withheld due to visa issues with Pakistan for American operatives. It was declared that Pakistan was deliberately impeding the visa process. Pakistan declared that these matters did not have any impact on bilateral relations and Pakistan was able to carry out operations (Kronstadt, 2012).

\subsection{US and military regimes}

Post 9/11 preferences in Pakistan were weighed according to United States' interests in Pakistan and the region. During 1990s, United States did not support democracies in Pakistan when it left the region after Soviet evacuation from Afghanistan. The efforts after 9/11 to reinvigorate the relations with Pakistan were vested in long term US' regional interests in the region despite the fact that Pakistan had military dictator. At that time Pakistan was under 'democracy sanctions' (Sattar, 2010). The later decade was marked by remarkable cooperation.

Energy of the US-Pak relations could be assessed from the aid given to military governments 
in Pakistan. During the military rules the aid extended to Pakistan stands at \$ 382.9 million. But the aid given to civilian governments since independence is $\$ 178.9$ million (Ali, 2009). This figure plausibly shows the tilt of US in Pakistan towards military governments. This partnership is clearly based on goods this engagement brought to United States. The bilateral engagement between Bush administration and Musharraf government had gains for both. Musharraf government needed the support to establish his government. Immediately after 9/11 the support in Pakistan was not for internal stability in Pakistan but for counterterrorism and counterinsurgency goals. Sanctions were waived and Pakistan was promised $\$ 2$ billion debt relief (Cohen, 2007). Later, the civilian government was assured similar support through aid extension in form of Kerry Lugar Bill. But this era of partnership faced serious differences due to many irritants. These events spoiled the relationship and level of trust reduced. These factors added to create 'trust deficit'. Now when US is planning to withdraw from Afghanistan again, the preferences are changing again. Before leaving, United States has concluded that now AlQaeda anymore from Afghanistan does not threaten it (Salim et al., 2020). The upcoming era may be of divergence of interests again and may add to 'trust deficit'.

The level of bilateral understanding seems to be higher with Musharraf regime. The irritants were managed somehow smoothly during his rule. History shows that military regimes were more favoured by US governments in Pakistan. Coincidentally, the US interests tipped to very high point in the region with takeover of military regimes in Pakistan. The blowback of decision to join US alliance to fight War on Terror could be better absorbed by military regime in absence of parliament instead of democratically elected government. And it actually did. Democracy had been weak in Pakistan and the lack of political consensus on foreign policy decisions regarding US in Pakistan hinders the way to smooth engagement with it during democratically elected governments in Pakistan.

\section{Conclusion}

Aid, irritants and the forms of government in Pakistan affect Pak-US relations. The priority on part of United States is its regional interests. Pakistan remained flawed in advocating its national interests while bargaining with United States. During every phase of high ebb of engagement Pakistan failed to tout its long-term interests. The engagement remained confined to phased and low level of cooperation marked by blame game from US. The aid played a weighty role in determining relationship. But still Pakistan believed the aid extended to it did not match the level of economic loss it bore due to War on Terror. Additionally, there is huge deficiency of recognition of role it played to make world a safer place. Pakistan's dependence on aid was the key factor behind this commitment. The aid was the major attraction for Pakistan owing to its dependency. The trust deficit between both states decreased due to many events which created gulf between both states. The events derailing bilateral engagement always emerged out of inconsistency of interpretations due to varied national interests. US declined to acknowledge Pakistan's compulsions and blamed it for playing double games. At some instances, Pakistan's national integrity was hurt but US refused to take note of it. US military establishment deliberates over Pakistan from its Central Command and entirely eyes it from its own prism reflecting its own interests. This prism breaks the regional security complex of which Pakistan is most important actor. Indo-US proximity plausibly disturbs the regional balance of power as Pakistan's foreign policy is determined majorly by Indian threat. US negation of giving Pakistan equal status as to India and declining it complete right to maintain its security on equal footings to balance regional security matrix becomes a thorn in relations. 


\section{References}

Aguirre, P. (2019). Cooperation or Conflict: Using Alliance Theory to Explain the Current Gulf Cooperation Council Crisis. https://opencommons.uconn.edu/srhonors theses/616/

Ahmad, N. (2016). Re-defining US-Pakistan Relations. Pakistan Journal of International Relations,

14-23. https://www.qurtuba.edu.pk/thedialogue/The\%20Dialogue/7_3/Dialogue_July_Sept ember2012_211-233.pdf

Akhtar, S. (2012). Dynamics of USA-Pakistan relations in post 9/11 period: Hurdles and future prospects. International Journal of Humanities and Social Science, 2(11), 205-213. http://www.ijhssnet.com/journals/Vol_2_No_11_June_2012/23.pdf

Ali, M. (2009). US Foreign Aid to Pakistan and Democracy: An Overview. Pakistan Journal $\begin{array}{llll}\text { of Social } & \text { Sciences }\end{array}$ https://www.bzu.edu.pk/PJSS/vol29no2_2009/FinalPJSS7.pdf

Amin, R. U., Awan, G. M., \& Mahmood, A. (2020). PAK-US Relations: Paradoxes \& Enigmas during War on Terror. Sir Syed Journal of Education and Social Research, 3(3), 408-414. https://www.sjesr.org.pk/ojs/index.php/ojs/article/view/339

Beverley, E. L. (2020). Introduction: Rethinking Sovereignty, Colonial Empires, and NationStates in South Asia and Beyond, 40 (3), 407-420. https://doi.org/10.1215/1089201X$\underline{8747368}$

Burke, S. M., \& Ziring, L. (1990). Pakistan Foreign Policy: An historical analysis. Karachi: Oxford University Press.

Cohen, C. (2007). A perilous course: US strategy and assistance to Pakistan. Center for Strategic and International Studies.

Epstein, S. B., \& Kronstadt, K. A. (2013). Pakistan: US foreign assistance. Washington: Congressional Research Service. https://www.files.ethz.ch/isn/130530/211799.pdf

Khan, E., \& Ali, Q. (2019). Implications of 9/11 for Pak-US Relations. http://ijssa.com/index.php/ijssa/article/view/16

Khan, H. U. (2020). China, the emerging economic power: options and repercussions for Pak-US relations. International Politics, 1-26. https://link.springer.com/article/10.1057/s41311-020-00265-1

Khawaja, A. S. (2019). Pak-US relations: Victim of divergence of interests. PUTAJ Humanities and Social Sciences, 26(2). http://search.ebscohost.com/login.aspx?direct=true\&profile=ehost\&scope=site\&aut htype $=$ crawler \&jrnl $=2219245 X \& A N=146406367 \& h=z F F z u T H C g 4 w d f C q j N J 1 B p G$ qBdi9M1AeDtQ1dO7CSODpyuSpRwJ9rQhK9gKUSyLen1KhdQLk5RYHIkCUtp WQJsQ\%3D\%3D\&crl=c

Kronstadt, K. A. (2012). Pak-US relations. Washington: Congressional Research Service. https://search.proquest.com/openview/82b1c661bf611728e40e80222d36434d/1?pqorigsite $=$ gscholar $\& \mathrm{cbl}=2034880$

Mirza, M. N., \& Mushtaq, N. (2019). Pak-US relations: Transactional-transformational debate. Journal of Security and Strategic Analyses, 5(2), 27-49. https://search.proquest.com/openview/5a52a5cd94554919b1833aad9f64513a/1?pqorigsite $=$ gscholar \&cbl $=4792524$

Nawaz, S. (2011). Who controls Pakistan's Security Forces. US Institute of Peace. http://www.jstor.com/stable/resrep12402

Niazi, K. M. K. (2017). Pak-US relations during Musharraf regime, an analytical study (doctoral dissertation). 
http://121.52.159.154:8080/jspui/bitstream/123456789/551/1/PAK\%20US\%20REL ATIONS\%20DURING\%20MUSHARRAF\%20REGIME\%2C\%20AN\%20ANALY TICAL\%20STUDY.pdf

Rafique, N. (2011). Rethinking Pakistan-US relations. Strategic Studies, 31(3), 124-152. https://www.jstor.org/stable/48527652

Raza, A. (2020). Pakistan in the New Great Game: The Way It Was. Pakistan Horizon, 73(3), $125-$

14.http://search.ebscohost.com/login.aspx?direct=true\&profile=ehost\&scope=site \& authtype $=$ crawler $\&$ jrnl $=0030980 X \& A N=148251646 \& \mathrm{~h}=\mathrm{P} 5 \mathrm{G} 0 \mathrm{wzMQmiccHXIhXc}$ 13xMQuoHmObGk3kTD15iPJM0JhXLOFS1rd6cf9o3ndKK0vQ8ZR\%2BiN703sf NGq2TDmFAQ\%3D\%3D\&crl=c

Rizvi, H. A. (2005). Theoretical formulations on Terrorism. In: Global Terrorism, genesis, implications, remedial and counterterrorism. Islamabad: Institute of Regional Studies.

Salim, A., Semetko, H. A., Zehraa, S. (2018). Pak-US Strategic Partnership and Challenge of Internal Radical Symbiosis. Liberal Arts and Social Sciences International Journal (LASSIJ), 2(1), 57-64. https://doi.org/10.47264/idea.lassij/2.1.7

Salim, A., Khan, R., \& Zikriya (2020). US-Taliban Peace Agreement: A Study of Economic and Strategic Implications for Pakistan. Liberal Arts and Social Sciences International Journal (LASSIJ), $\quad 3(2), \quad 158-165$. https://doi.org/10.47264/idea.lassij/3.2.18

Saniel, J. (2018). The Erosion of the Bi-Polar Power Structure in the 1960s: Its Impact Upon East Asian International Politics (1973). Asian Studies: Journal of Critical Perspectives on Asia, 54 (1/2), 145-189. https://www.asj.upd.edu.ph/mediabox/archive/ASJ_54_2018/06_Erosion_Bipoloar_ Power_Structure 1960s_Impact East_Asian_International_Politics.pdf

Sasikumar, K. (2017). After nuclear midnight: The impact of a nuclear war on India and Pakistan. Bulletin of the Atomic Scientists, 73(4), 226-232. https://www.tandfonline.com/doi/abs/10.1080/00963402.2017.1338009

Sattar, A. (2010). Pakistan's foreign policy (1947-2009): A concise history. Oxford University Press. 18-19. http://sanipanhwar.com/Pakistans\%20Foreign\%20Policy\%201947\%202009.pdf

Saud, A., \& Arif, K. (2018). US-India strategic alliance and CPEC 'the game changer': Prospects for Pakistan and Russian cooperation. Central Asia, 83, 19-43. http://www.asc-centralasia.edu.pk/index.php/ca/article/download/27/25

Sohrab, W., \& Chaudhary, I. A. (2012). Pak-US Relations in 21st Century: Challenges and opportunities for Pakistan. Berkeley Journal of Social Sciences, 2(3), 1-16. https://hostnezt.com/cssfiles/currentaffairs/PAKUS\%20RELATIONS\%20IN\%2021 ST\%20CENTURY\%20CHALLENGES\%20AND\%20OPPORTUNITIES\%20FOR \%20PAKISTAN.pdf

Times, N. Y. (2011). US Admiral ties to Pakistan killing of Journalist. New York Times. https://www.ndtv.com/world-news/us-admiral-ties-pakistan-to-killing-of-journalist$\underline{460788}$

Timothy, H. (2011, July). Pakistan: An ally by another name. Proceedings: Pakistan unlikely to help in War. Associated Press.

Wood, R. S. (2006). Tobacco's tipping point: The master settlement agreement as a focusing event. Policy Studies Journal, 34(3), 419-436. https://onlinelibrary.wiley.com/doi/abs/10.1111/j.1541-0072.2006.00180.x 